man who probably knew his "Plains" better than any other, but also a genuine effort at co-ordination and presentation of the results of carefully focused investigations. It might, however, have been substantially improved by a more complete summary of the present position of our knowledge, by way of introduction to the several contributions, than is attempted in the brief foreword; this, though sufficiently lucid so far as it goes, still leaves to the reader the task of fitting together the various pieces of evidence to make a pleasingly intelligent picture of the whole.

\section{Index of Publications of the Royal Society}

THe Royal Society has issued in one alphabet an author index to its Proceedings, Series A and B, from 1905 to 1930 , and to the Philosophical Transactions, Series A and B, from 1901 to the same year, the entries being arranged chronologically under each heading. A previous index to the Proceedings was published in 1913, which covered the period from 1800 (when the series began under the title "Abstracts of Papers printed in the Philosophical Transactions") to the year 1904, so that the author index to this publication is now complete to the year 1930. The only indexes to the Philosophical Transactions hitherto available have been author and subject indexes down to the year 1830, but the "Catalogue of Scientific Papers", which includes papers in the Philosophical Transactions, may be considered to continue the indexing under authors' names down to the year 1900, whence the new volume completes it to the year 1930 . So far as the author index is concerned, therefore, the indexing of the two publications is available for their entire runs. A subject index from 1800 is still lacking, except in so far as the mathematical, mechanical, and physical papers for the period 1800 1900 are concerned, since these have been included in the three published subject indexes to the "Catalogue of Scientific Papers", which covers both publications.

\section{Science and Letters in Poland}

THE principal contribution to vol. 15 of Nauka Polska (Polish Science), which has recently appeared, is Prof. Z. Szweykowski's account of the Institute for the Promotion of Science and Letters in Poland. This Institute, which is to-day under the patronage of Prof. I. Mościcki, the President of the Polish Republic, and himself a distinguished chemist, was founded in 1881 in difficult circumstances from the Mianowski Fund. It has had a chequered history, but the Mianowski Institute now occupies the spacious Staszic Palace, and its future is assured. The aim of this Institute is the furtherance of all branches of science in Poland. It has already published or supported financially the publication of 1200 volumes and the preparation of 200 scientific works, and has subsidised fifty scientific periodicals. In addition, it has made grants to some fifty societies, research laboratories, and museums. The same volume of Nauka Polska includes a comprehensive survey of the progress of science in Poland between 1800 and 1880 by Prof. F.
Bujak. It constitutes a summary of the works of Polish men of science during the greater part of last century. Other articles deal with the present-day needs of applied physics, the position of the State libraries in Poland, and the scope and organisation of the Institute for Slavonic Studies.

\section{Habits of Bats}

IN the Journal of Mammalogy for May (p. 133) Mr. C. E. Johnson gives some notes on a family of red bats (Lasiurus borealis borealis) in captivity, and mentions that theold female, when let looseindoors, alighted more than once on the floor, and rose as easily as a bird. In the eighteenth century, Gilbert White alludes to a tame bat he saw, which several times confuted the vulgar opinion that bats could not rise from a flat surface, by rising with great ease from the floor; and the writer of this note has found the common yellow bat of India (Nycticejus kuhli) and the collared fruitbat of Africa (Rousettus leachi) also quite able to take wing from the flat. These examples are worth giving because the error mentioned by White still persists, and in quarters where 'vulgar opinion' might not be supposed to be the vogue. The fact is that a bat does not voluntarily remain on the flat in the open, but may no doubt be found there unable to rise owing to some incidental disability, just as a man may be found lying helpless on a pavement for a similar reason.

\section{Safety in Mines}

THE Safety in Mines Research Board has recently issued its tenth Annual Report, which contains a good. deal of matter of scientific interest. Perhaps the part that will be most widely read is Appendix No. 9, which refers to researches intended to obviate fatalities from falls of ground. It commences by a record of researches on the strength of supports, etc., carried out under the direction of Prof. S. M. Dixon, and, furthermore, contains summaries of the results obtained by the various district committees working on the subject throughout Great Britain. The body of the Report shows considerable activity on the part of the Board, and indicates how greatly the scope of the work has been extended and how much has been done to make the results accessible to mining men generally. It must, however, be admitted that the work so far has been rather of the nature of collecting scientific material which will, no doubt, be useful at some future date in increasing the safety of mining, for up to the present the results obtained are of scientific interest rather than of practical importance.

\section{American Railway Progress}

THE issue of the Journal of the Franklin Institute for March contains the address of Mr. W. C. Dickerson, president of the American Locomotive Company, on the progress made during the interval 1920-30. The 15 charts reproduced allow it to be readily seen. The weight on the driving wheels of the goods locomotive has increased from 245 to 247 thousand pounds, but the drawbar pull, at 28 miles an hour, from 32 to 50 thousand. For the passenger locomotive the corresponding figures are 192 to 187 and 18 to 44 thousand 